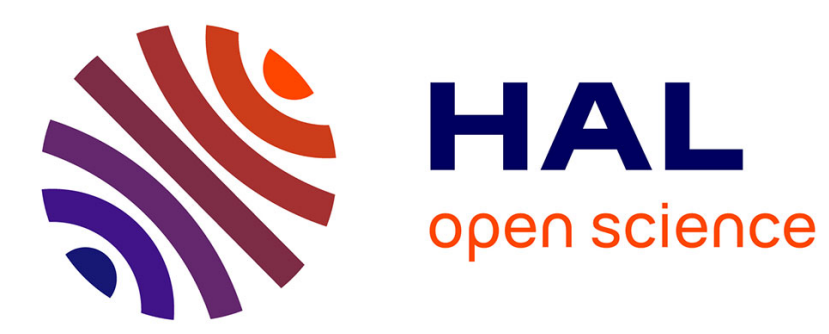

\title{
The effect of Microstructure on the mechanical properties and adiabatic shear band formation in a medium carbon steel \\ E. Cepus, C. Liu, M. Bassim
}

\section{- To cite this version:}

E. Cepus, C. Liu, M. Bassim. The effect of Microstructure on the mechanical properties and adiabatic shear band formation in a medium carbon steel. Journal de Physique IV Proceedings, 1994, 04 (C8), pp.C8-553-C8-558. 10.1051/jp4:1994886 . jpa-00253447

\section{HAL Id: jpa-00253447 https://hal.science/jpa-00253447}

Submitted on 1 Jan 1994

HAL is a multi-disciplinary open access archive for the deposit and dissemination of scientific research documents, whether they are published or not. The documents may come from teaching and research institutions in France or abroad, or from public or private research centers.
L'archive ouverte pluridisciplinaire HAL, est destinée au dépôt et à la diffusion de documents scientifiques de niveau recherche, publiés ou non, émanant des établissements d'enseignement et de recherche français ou étrangers, des laboratoires publics ou privés. 


\title{
The effect of Microstructure on the mechanical properties and adiabatic shear band formation in a medium carbon steel
}

\author{
E. Cepus, C.D. Liu and M.N. Bassim \\ Department of Mechanical and Industrial Engineering, University of Manitoba, Winnipeg Manitoba R3T \\ $2 N 2$, Canada
}

\begin{abstract}
Resumé
Des essais de déformation à haute vitesse utilisant une barre d'Hopkinson en torsion ont été faits sur un acier a teneur de carbone moyen soumis a des traitements thermiques différents. Les essais avaient un taux de déformation de $1000 \mathrm{~s}^{-1}$. Les traitments thermiques étaient les suivants: tel que reçu, recuit et refroidi dans l'air, et soumis à un traitment de trempe et revenu a 315,480 at $650^{\circ} \mathrm{C}$ pendant une heure. Les microstructures observées étaient soit une pearlite épaisse, une pearlite non-dissoute dans une matrice de ferrite et trois variétés de martensite revenues. On a observé que la ferrite se déforme préférentiellement par rapport aux autres composants dans la microstructure. Aussi, quand la ferrite est uniforme, les bandes de cisaillement adiabatique sont aussi uniformes. Mais, quand la ferrite est ségrégée, les bandes de cissaillement observées sont plutot granulaires.
\end{abstract}

\begin{abstract}
Using a torsional split-Hopkinson bar, high strain rate tests in the order of $1000 \mathrm{~s}^{-1}$ were conducted on 5 different heat treatments of a medium carbon steel. The heat treatments were; as received, fully annealed and air cooled and quench tempered at 315,480 and $650^{\circ} \mathrm{C}$, each for 1 hour. The microstructures obtained were coarse pearlite, unresolved pearlite in a ferrite matrix and three different tempers of martensite. It was found that ferrite in the microstructures would always deform preferentially over any other phase present in the material. In addition, if the ferrite was uniformly distributed, the ASB would be uniformly deformed. However, when it was segregated, granular type shear band surfaces would be observed.
\end{abstract}

\section{INTRODUCTION}

Adiabatic shear bands (ASB's) have been studied in applications ranging from high speed forming to machining chips [1,2,3] dating back to the 30's [4]. But since their first observation, the strongest proponent of the research has been the military $[5,6,7,8,9,10]$, having an extremely crucial invested interest in the behaviour of metals under ballistic impact and their subsequent properties during ASB formation. 
In this study, the effect of microstructure, including the presence of ferrite, pearlite and martensite will be examined to determine their relationship with the materials mechanical properties such as the yield stress, hardness and ductility as well as the width and type of ASB at high rates of strain.

\section{EXPERIMENTAL INFORMATION}

The tests were done using a torsional Kolsky bar (split-Hopkinson bar), with a setup similar to the type described by $[7,8,11$,$] at strain$ rates approximately $1000 \mathrm{~s}^{-1}$.

The specimens were tested at five microstructural conditions; as received,

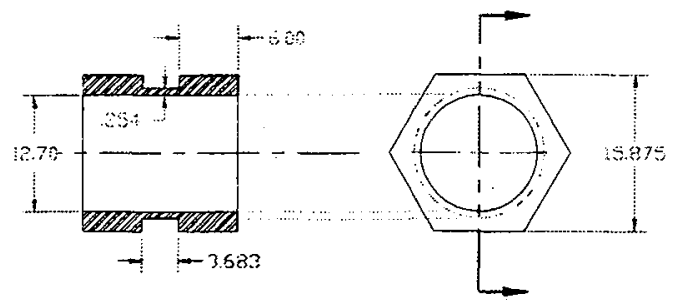

Figure 1. Geometry of the torsional specimen. Dimensions in $\mathrm{mm}$ annealed at $850^{\circ} \mathrm{C}$ for 1 hour then air cooled and austenized at $850^{\circ} \mathrm{C}$ for 1 hour, oil quenched then tempered for 1 hour at 315,480 and $650^{\circ} \mathrm{C}$. Specimen composition is given in Table 1 and specimen geometry is as shown in Figure 1. The gage section was polished to a $6[\mu \mathrm{m}]$ diamond paste finish.

\begin{tabular}{cccccccc}
\hline \multicolumn{7}{c}{ Table 1. Percent composition of SPS-PlusData from Atlas Alloys. } \\
\hline & $\mathrm{C}$ & $\mathrm{Mn}$ & $\mathrm{Si}$ & $\mathrm{Ni}$ & $\mathrm{Cr}$ & $\mathrm{Mo}$ \\
\cline { 2 - 8 } SPS -Plus & 0.42 & 1.18 & 0.29 & 0.41 & 0.95 & 0.06 \\
\hline
\end{tabular}

\section{RESULTS AND DISCUSSION}

\subsection{Material Microstructures}

The microstructures obtained, revealed using 2\% Nital, are illustrated in Figures 2(a) through 2(e), inclusive, hereafter referred to as A, B, C, D and E. Figures 2(a) and 2(b) are both pearlite outlined with some ferrite at the previously austenitic grain boundaries. The only difference between the two is that $A$ was cooled slower than $B$ and thus consists of a visibly coarser pearlite. In any case, the regions which seemed more resistant to the etchant are some variety of pearlite while the ferrite is etched preferentially, as is expected [12]. A microstructure consisting of a very fine and uniform lathe type martensite with a few precipitates interspersed within the matrix is shown in Figure 2(c). Precipitate analysis via EDS confirmed the presence of magnesium, aluminum and oxygen. The early visible stages of martensitic recovery and recrystallization are shown in Figure 2(d). The micrograph is visibly coarser than in Figure 2(c) and precipitates increase in size and number. Also, the martensitic cells appear to be increasingly segregated from each other with ferrite [13]. The final microstructure, Figure 2(e), is an extrapolation of the changes noticed from Figures 2(c) to 2(d). The martensite morphology has become very coarse and the grain boundaries compose a much larger fraction of the area than is seen in Figure 2(d), with ferrite now much more uniformly distributed throughout the matrix. The precipitates have either become very large and fallen out of the sample during preparation, or have diffused back into the matrix - probably the ferritic grain boundaries.

\subsection{Mechanical Properties}

Typical high strain rate stress-strain curves for each of the 5 specimens are given in Figure 4 . As one can see from Figure 4, there are definite material property changes depending on the specimens microstructure. Samples A and B have roughly the same ductility but a drastic difference in the yield stress. The 3 tempered samples display a more complex mechanical property interrelation. C and D are of roughly the same strength, with D being nearly twice as ductile. An interesting observation is how $E$ drastically reduces its yield stress and becomes by far the most ductile of all the 5 sample types. The mechanical properties and hardnesses for each heat treatment are summarized in Table 2 


\subsection{Adiabatic Shear Band Micrographs}

Figure 3(a) through 3(e) inclusive, show the region of the sample right beside the ASB induced crack. Each of the 5 micrographs is shown unetched and at the same magnification. It can be seen that the less ductile samples had the narrowest ASB's. In addition, a more uniform material microstructure results in uniform ASB's. Figures 3(b) and 3(d) being examples of a highly segregated microstructure with equally inhomogeneous shear bands. Shear band width and local strain are summarized in Table 2 . Analysis of the micrographs in Figure 3(a) through 3(e) seem to indicate that the presence of ferrite greatly influences both the mechanical properties and the nature of the shear band observed. In sample $\mathrm{A}$, the coarse pearlite structure is very rich in ferrite both within the pearlite itself and in the previously austenitic grain boundaries. The post mortem micrograph shows a very fibrous, homogeneous ductile type of fracture mechanism occurring. This agrees well with the ductility one expects a coarse pearlitic material to possess. Sample B, as described earlier, is composed of unresolved pearlite and ferrite, of which the pearlite is much stronger. Examination of Figure 3(b) shows what seems to be inhomogeneous intergranular deformation. The harder, stronger fine pearlite cells show more resistance to deformation than the surrounding ferrite and, thus, it is the ferrite which takes up most of the deformation of the material. A drastic change in the ASB, as shown in sample C, Figure 3(c), is noticed compared to the previously discussed samples $A$ and $B$. This is because sample $C$ consists of a fine martensitic structure. Examination of the shear band region shows the deformation band to be very narrow in comparison to the others, implying a lack of ductility, as well as being very uniform due to the uniform nature of the martensitic structure. In sample D the effects of the tempering on the yield stress and ASB structure, shown in Figure 3(d), are beginning to become much more noticeable. The previously described ferrite boundaries beginning to form will deform preferentially over the, still very hard, martensitic cells they surround. Figure 5, an etched version of Figure 3(d), demonstrates this suspicion. Though the separation between the cells appear to be brittle type cracks, close examination reveals them to be fibrous in nature, lending credibility to the argument that the ferritic structures are responsible for the ductility of the sample. In the final sample, $\mathrm{E}$ in Figure 3(e), the tempering process has dramatically altered the microstructure. The presence of ferrite is far more prevalent and uniform than in sample $D$. The result is a shear band far more uniform and ductile in appearance than was shown for sample D and, in fact, the most ductile sample tested.

\section{CONCLUSION}

In conclusion, it appears that any heat treatment responsible for the increase in ferrite of the sample will correspondingly increase its ductility. Ferrite, since being the softest of the phases studied here will deform preferentially over either pearlite or martensite. If the pearlite is sufficiently coarse, the lamellar spacing will be great enough such that the ferrite between the cementite layers will be in great enough proportion to deform, giving rise to a homogeneously deformed shear band. In instances where the spacing is very small and the pearlite is highly unresolved it will have a much higher percentage of cementite and therefor be much harder and resistant to deformation than the surrounding ferrite, causing granular type shear banding. In the case of martensitic microstructures, the deformation is uniform until the amount of ferrite is increased through tempering, at which point the ferrite will deform preferentially while the martensite remains virtually undeformed.

\section{ACKNOWLEDGEMENT}

The authors would like to acknowledge the Natural Sciences and Engineering Research Council for support of this investigation. 


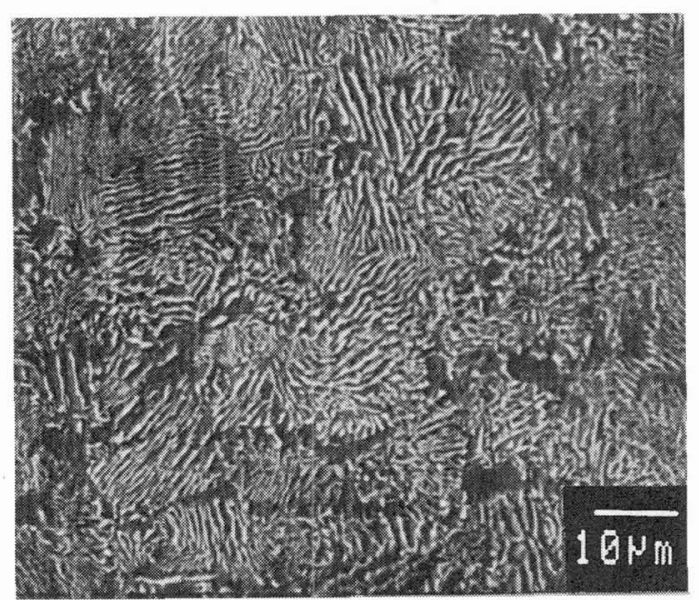

a) As received.

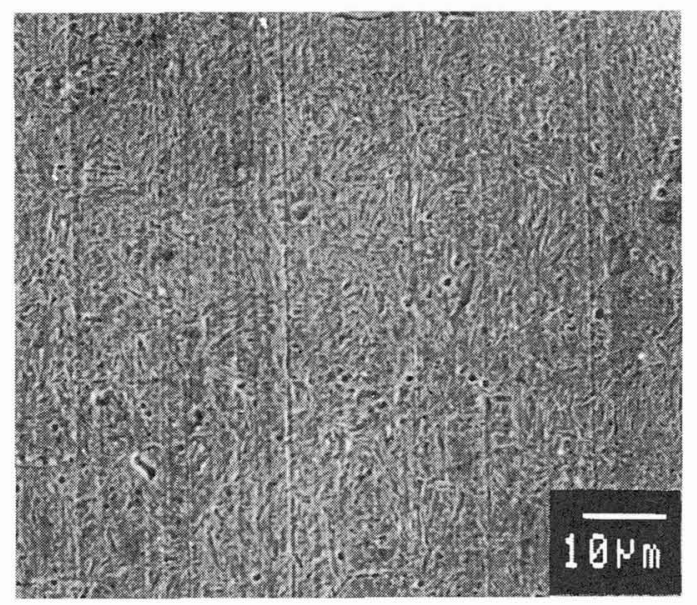

c) Quench tempered at $315^{\circ} \mathrm{C}$.

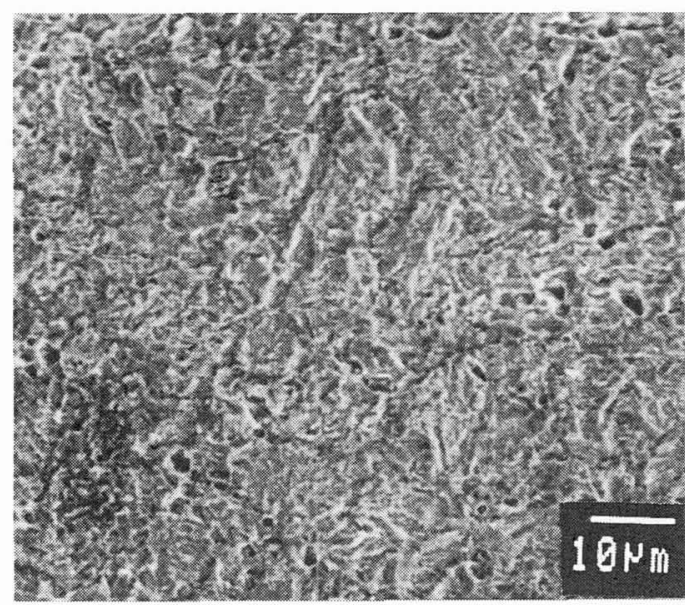

e) Quench tempered at $650^{\circ} \mathrm{C}$.

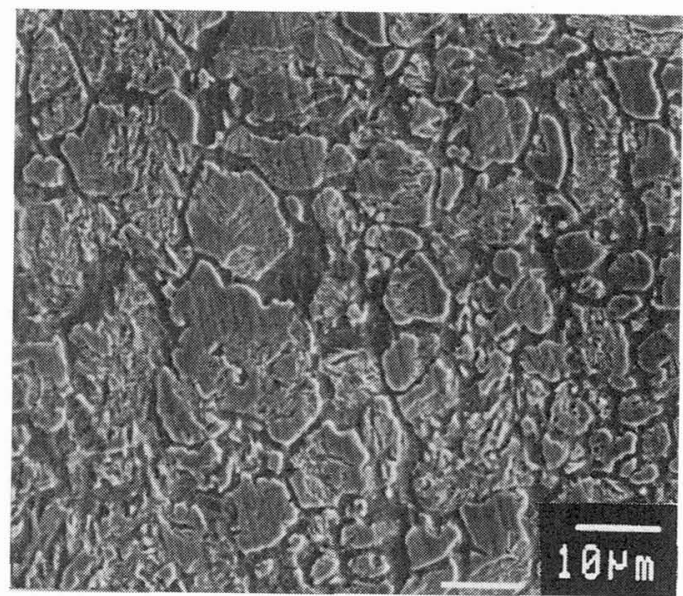

b) Fully annealed, air cooled.

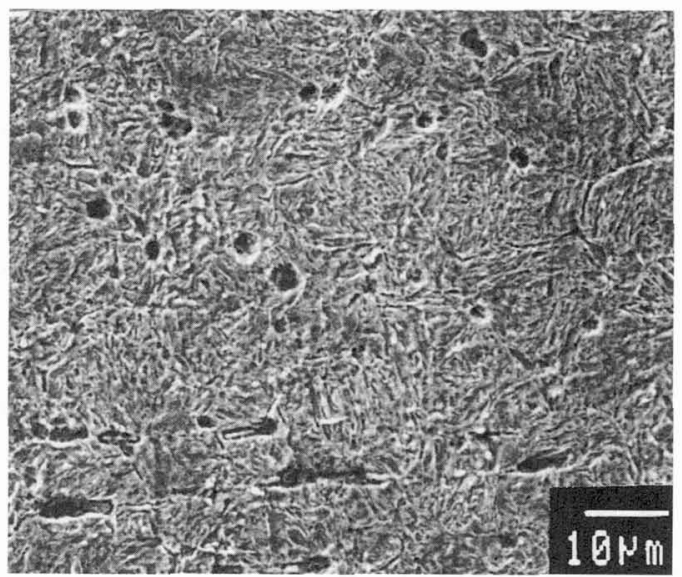

d) Quench tempered at $480^{\circ} \mathrm{C}$.

Figure 2. Microstructure of SPS-Plus steel heat treated at 5 different conditions. 


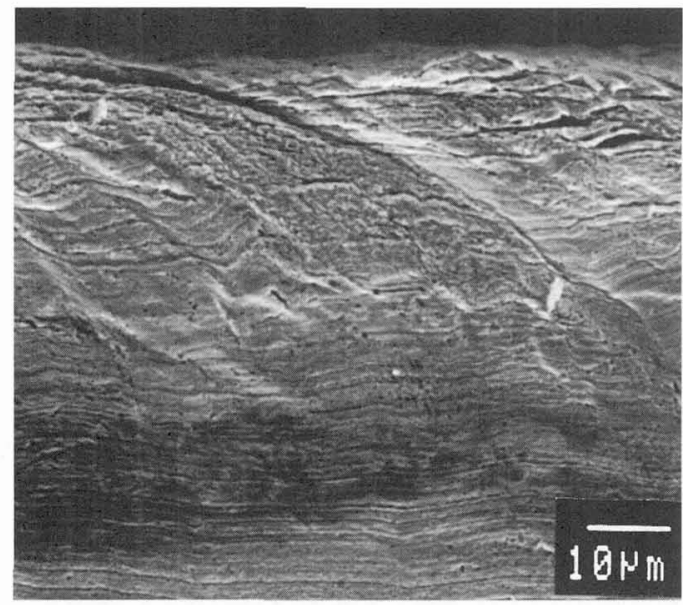

a) As received.

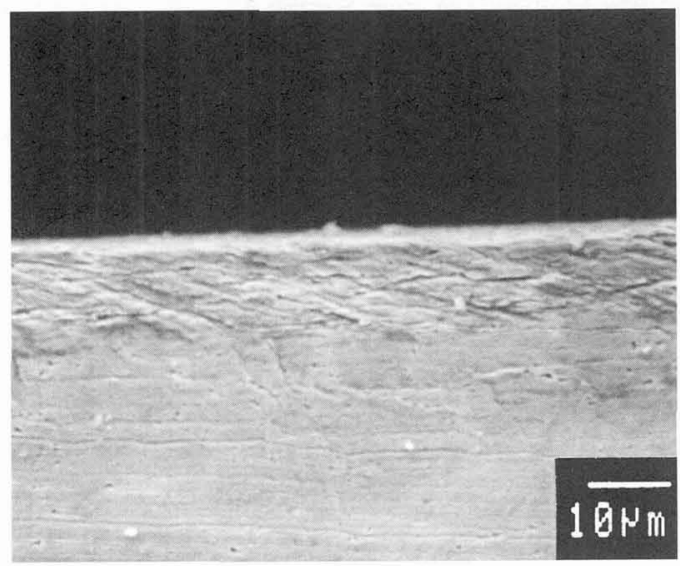

c) Quench tempered at $315^{\circ} \mathrm{C}$.

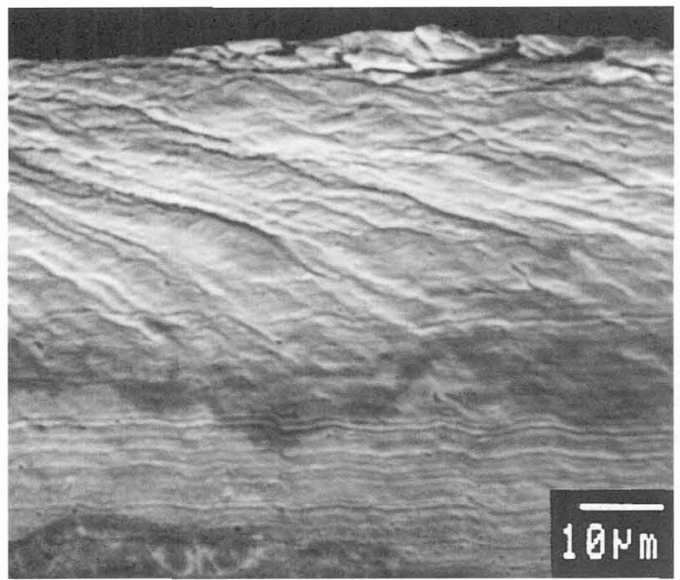

e) Quench tempered at $650^{\circ} \mathrm{C}$.

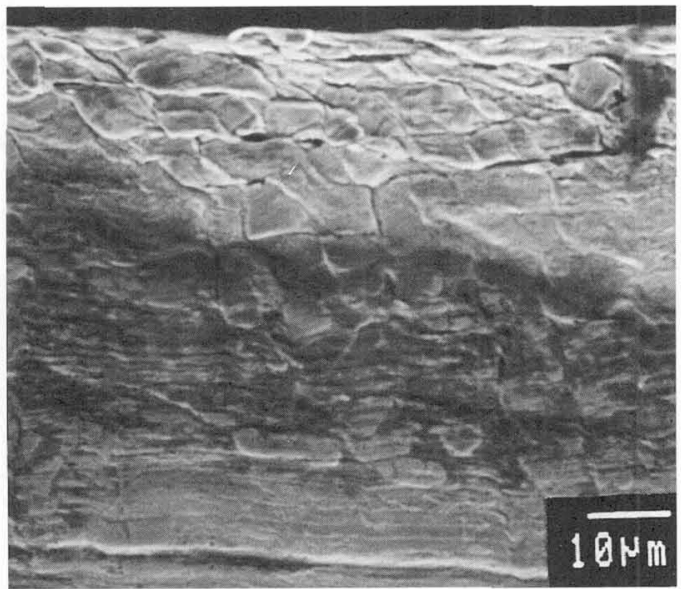

b) Fully annealed, air cooled.

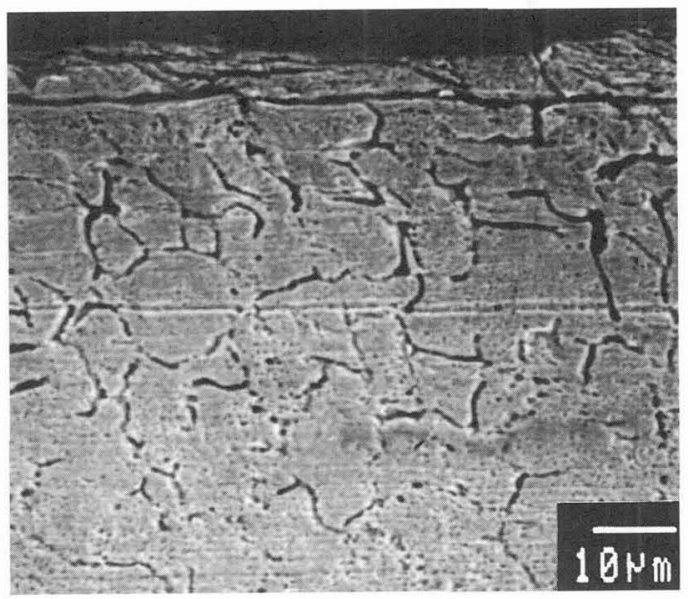

d) Quench tempered at $480^{\circ} \mathrm{C}$.

Figure 3. Micrographs of the ASB's for each of the material types. 


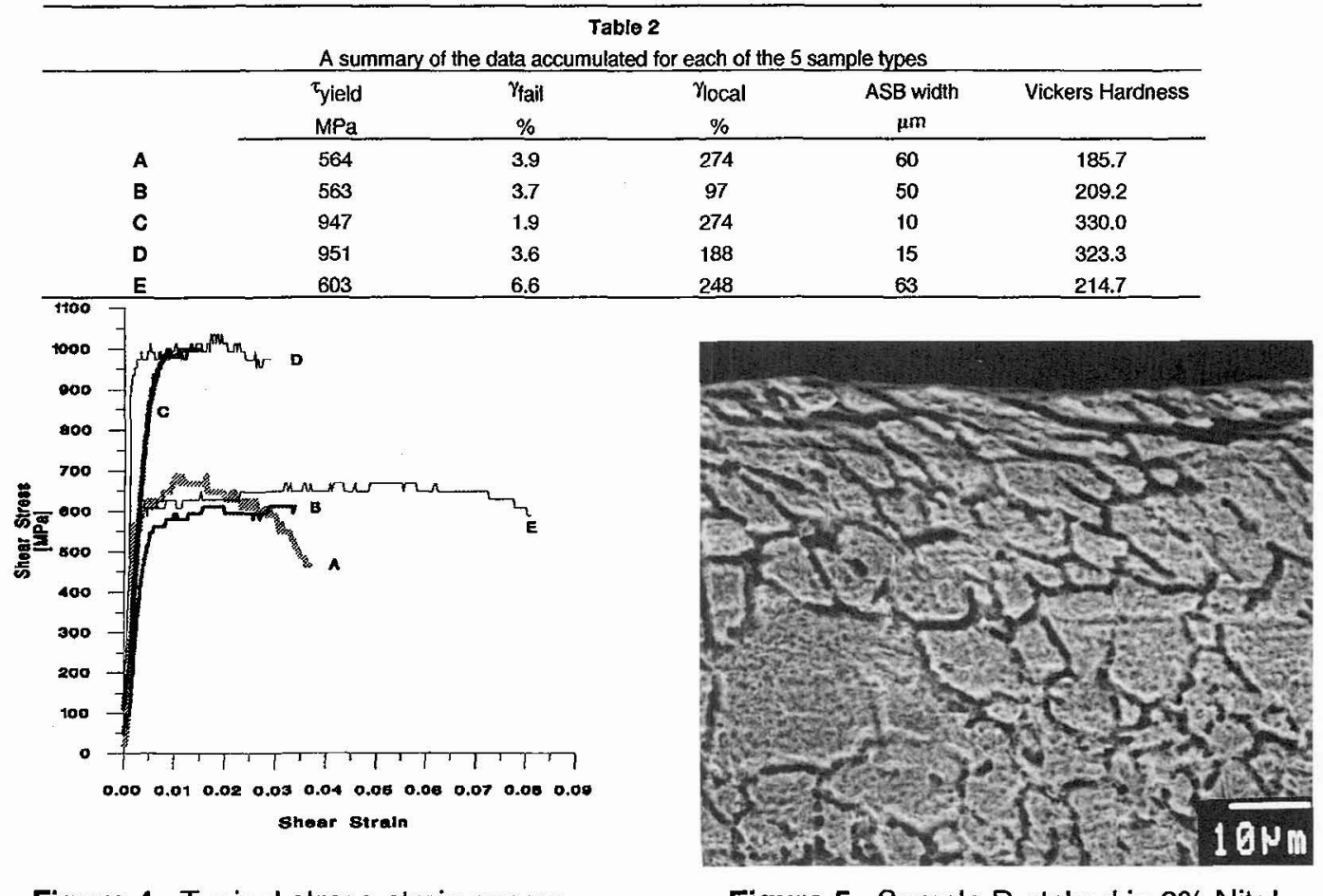

Figure 4. Typical stress-strain curves.

Figure 5. Sample D etched in 2\% Nital.

\section{REFERENCES}

[1]Turley D.M., Doyle E.D. and Ramalingam S., Materials Science and Engineering 55 (1982) 45-48.

[2] Lemaire J.C. and Backofen W.A., Metallurgical Transactions 3 (1972) 477-481.

[3] Dao K.C. and Shockey D.A., J.Appl.Phys. 50 (1979) $8244-8246$

[4] Itahara, M. "Impact Torsion Tests", Technical Reports of Tohoku Imp. University, 9, 16, 11, 512 and $12,173(1933-35)$

[5] Hartley K.A., Duffy J. and Hawley R.H., J.Mech.Phys.Solids, 35 (1987) 283-301.

[6] Backman M.E. and Finnegan S.A., Metallurgical Effects at High Rates of Strain (Plenum Press, New York, 1973) pp. 531-543.

[7] Costin L.S., Crisman E.E., Hawley R.H. and Duffy J., Inst.Phys.Conf. Ser, 47 (1979) 90-100.

[8] Senseny P.E., Duffy J. and Hawley R.H., Journal of Applied Mechanics, 45 (1978) 60-66.

[9] Olson G., Mescall J.F. and Azrin M., Shock Waves and High-Strain-Rate Phenomena in Metals (Plenum Press, New York, 1981) pp 221-247.

[10] Rogers H.C. and Shastry C.V., Shock Waves and High-Strain-Rate Phenomena in Metals (Plenum Press, New York, 1981) pp 285-298.

[11] Duffy J., Campbell J.D. and Hawley R.H., J.Appl.Mech., 83 (1971) 83-91.

[12] Samuels L.E., Optical Microscopy of Carbon Steels (American Society for Metals, Metals Park, 1980) pg. 169.

[13] Samuels L.E., Optical Microscopy of Carbon Steels (American Society for Metals, Metals Park, 1980) pg. 375. 